\title{
鋼管の内圧クリープ破断について*
}

\author{
篠田璋** 玉田公*** 井上 靖介**

\section{Greep Rupture on the Tubular Specimens under Internal Pressure at High Temperature}

\author{
by \\ Noboru Shinoda, Isao Tamada and Yasusuke Inoue \\ (Research Department, Yawata Steel Tube Co., Ltd., Tokyo)
}

\begin{abstract}
In the tube design of boilers and other high temperature and high pressure installations, most of the tubes under internal pressure are designed on the basis of creep or creep rupture strength of simple tension bar specimens. In practice, these are used under multiaxial stresses. It is required therefore that the most representative formula will be determined experimentally which is to be applied to the designing of tubes subject to internal pressure at high temperature.

In the present study, the creep tests on tubular specimens of 18-8 Mo steel (thin-walled tube), $2^{1} / 4 \mathrm{Cr}-1 \mathrm{Mo}$ steel (thick-walled tube) and a low carbon steel (electric resistance welded tube) under internal pressure were carried out. The data of the stress rupture tests on tubular specimens were compared with those of simple tension bar specimens cut from the same tubes. The results are summarized as follows :

(1) A reasonable estimation of creep rupture life of the tube subject to internal pressure may be made from the uniaxial creep rupture data by using the Mean diameter formula. This agreement is independent of the steels, the size of the tubes, and of the temperature and time. The reason for this agreement is regared as the redistribution and the levelling of circumferential stress that occurred in the creep stage over the tube wall.

(2) The creep rupture test on the welded tube of a low carbon steel under internal pressure was carried out. The tube was the stretch reduced at $800^{\circ} \mathrm{C}$ after welding. In this test, the welded tube showed almost equivalent creep rupture strength as compared with the seamless tube.

(3) From this result, the welded tube can be used in high temperature service by giving proper treatment to eliminate the weld structure.
\end{abstract}

(Received Oct. 27, 1964)

\section{1 緒言}

ボイラ用鋼管や化学プラント等高温で内圧をかけて 使用される装置の設計には, 従来棒状試験片を用いて 一軸引張応力の下で試験されたクリープ強度あるいは クリープ破断強度が適用されてきたが，実際の使用中 の応力状態は多軸応力状態でありこれがクリープ変形 の進行と共に変化する．乙のような実際的な応力状態 におけるクリープ破断強度を求めようとして筆者らは さきに薄肉鋼管の内圧方りープ破断特性について研究 を行なつてきた。 こてではオーステナイト系18-8Mo 鋼薄肉鋼管, $2^{1} / 4 \mathrm{Cr}-1 \mathrm{Mo}$ 鋼厚肉鋼管，低炭素鋼溥 肉電縫鋼管の内圧クリープ破断の結果につき報告する.

* 原稿受理 昭和39年10月27日

** 八幡鋼管 (株) 研究部 東京都板橋区舟渡町三丁目2848

*** 正会員 " "
ここで電縫鋼管を取り上げたのは管の軸方向に溶接継 目が存在するため普通の方法ではそのクリープ破断強 度を求められないととおよび鋼管製造法の進歩により 経済的な意味でボイラ用鋼管として関心を集めている ためである.

$$
2 \text { 供 試 材 }
$$

この試験に用いた材料は $18-8 \mathrm{Mo}$ 鋼 (継目無鋼管), $21 / 4 \mathrm{Cr}-1 \mathrm{Mo}$ 鋼（継目無鋼管）および低炭素鋼（電 気抵抗溶接鋼管) でその化学成分を Table I 亿示す. 電縫鋼管と比較するため前に試験した低岸素鋼（継目 無鋼管) の化学成分も同時に示してある. 今回用いた 供試鋼管は機械加工を行なわない製管のままのもので ある. その試験片の形状および棒状試験片の形状寸法 を Fig. 1 亿示す. Table II 亿は鋼管試験片の寸法お よび熱処理を示す．棒状試験片は鋼管の軸方向から切 
Table I. Chemical composition.

\begin{tabular}{c|c|c|c|c|c|c|c|c}
\hline Material & G & Si & Mn & P & S & Gr & Ni & Mo \\
\hline $18-8$ Mo steel & 0.07 & 0.49 & 1.70 & 0.026 & 0.012 & 17.11 & 12.07 & 2.50 \\
\hline $\begin{array}{c}\text { Low carbon stecl } \\
\text { (Elec. resı. } \\
\text { weld. tube) }\end{array}$ & 0.12 & 0.28 & 0.48 & 0.013 & 0.024 & - & - & - \\
\hline $\begin{array}{c}\text { Low carbon steel } \\
\text { (Seamless tube) }\end{array}$ & 0.13 & 0.25 & 0.50 & 0.013 & 0.021 & - & - & - \\
\hline $21 / 4$ Cr-1 Mo steel & 0.11 & 0.23 & 0.48 & 0.010 & 0.008 & 2.18 & - & 0.90 \\
\hline
\end{tabular}

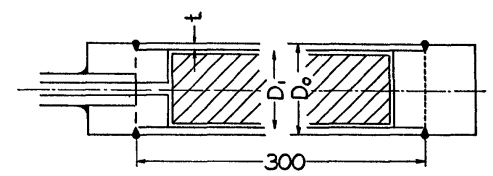

Tubular specimen

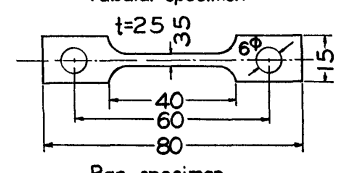

Bar specimen

Fig. 1. Test specimen.

Table II. Size and heat treatment of specimens.

\begin{tabular}{|c|c|c|}
\hline Materıal & Size $(\mathrm{mm})$ & Heat treatment \\
\hline 18-8 Mo stecl & $\begin{array}{l}D_{0}=30.0 \quad t=2.2 \\
D_{1}=25.6\end{array}$ & $1100^{\circ} \mathrm{C} \times 1 / 2 \mathrm{hr} \rightarrow \mathrm{WQ}$ \\
\hline \multirow{2}{*}{$\begin{array}{l}\text { I.ow carbon steel } \\
\text { (Flec. resı. weld. } \\
\text { tube) }\end{array}$} & \multirow{2}{*}{$\begin{array}{l}D_{0}=27.2 t=3.0 \\
D_{1}=21.2\end{array}$} & (1) $\begin{array}{l}\text { Elec. } \\
\text { weld }\end{array} \stackrel{\text { resı. }}{\rightarrow} \underset{\text { reduce }}{800^{\circ} \mathrm{C} \text { stretch }}$ \\
\hline & & (II) E.R.W $\underset{\mathrm{S} . \mathrm{R}}{800^{\circ} \mathrm{C}} \rightarrow \underset{\text { rmalize }}{900^{\circ} \mathrm{C}}$ No- \\
\hline \multirow[t]{2}{*}{$21 / 4 \mathrm{Cr}-1$ Mo steel } & $D_{0}=33.7 t=5.85$ & \multirow{2}{*}{$900^{\circ} \mathrm{C} \times 1 \mathrm{hr} \underset{\mathrm{A} . \mathrm{C}}{1000^{\circ} \mathrm{C} / \mathrm{hr}} \rightarrow 600^{\circ} \mathrm{C} \rightarrow$} \\
\hline & $D_{1}=22.0$ & \\
\hline
\end{tabular}

り出したものである，低炭素鋼電縫鋼管はSiキルド鋼 で，低周波電気抵抗溶接により製管後 $800{ }^{\circ} \mathrm{C}$ 亿絞り 圧延を行ない（I）絞り圧延のまま，（II）絞り圧延後 $900{ }^{\circ} \mathrm{C}$ て焼準したものの 2 種類について 試験を行な った. との電縫ボイラ用鋼管は初期の試作品の一つで, 現在の立場からみれば鋼種, 溶接法等必ずしも最良と は考えられないが，管軸方向に溶接継目のある電縫鋼 管のクリープ破断強度を求めること, および溶接後高 温において絞り圧延を行なうことによる熱処理効果を 知るためである.

\section{3 試験装置および試験方法}

試験装置は前報に述べたものと同じで，水圧ポンプ により試験片に高圧水を封入し，試験片は堅型電気炉 で加熱している. 試験片の中には中子を入れて温度変 動によって起てる圧力の変動および破断時の爆発力を 少なくしている. 試験可能温度範囲は $300 \sim 800^{\circ} \mathrm{C}$, 精 度は土 $3 \sim 4{ }^{\circ} \mathrm{C}$, 圧力範囲は $0 \sim 1000 \mathrm{~kg} / \mathrm{cm}^{2}$, 精度
は設定值の約 $1 \%$ 前後である. 圧力調節はリザーバの 水温を加減するととにより行なっている.

鋼管の内圧クリープ破断強度と一軸引張クリープ破 断強度の関連性を比較検討するために, 内圧クリープ 破断試験の結果は下記のような三つの設計基準式を用 いて整理した。

$$
\begin{array}{ll}
\text { Barlow の式 } & \sigma=\frac{P}{2} \frac{D}{t} \\
\text { 平均径の式 } & \sigma=P\left[\frac{1}{2} \frac{D}{t}-0.5\right] \\
\text { ASME の式 } & \sigma=P\left[\frac{1}{2} \frac{D}{t}-y\right]
\end{array}
$$

（yは鋼種と温度によるパラメータで $0.4 〜 0.7$ の值 をとる. $\sigma$ : 応力 $P$ : 内圧 $D$ :管の外径 $t$ : 管の 内厚)

高温における鋼管の内圧クリープ破断試験において てれらの式により与えられる応力値はある時間で鋼管 が破壊する応力で，同じ材料の一軸クリープそおいて 同じ時間に破断する応力に最も近いものが最も信頼し 得る式というととになる.

試験片は試験にさきだち約 20 時間所定温度に保持し た後圧力を負荷した.

\section{4 試 験 結 果}

Fig. 2は 18-8Mo 鋼継目無鋼管の内圧クリープ破断

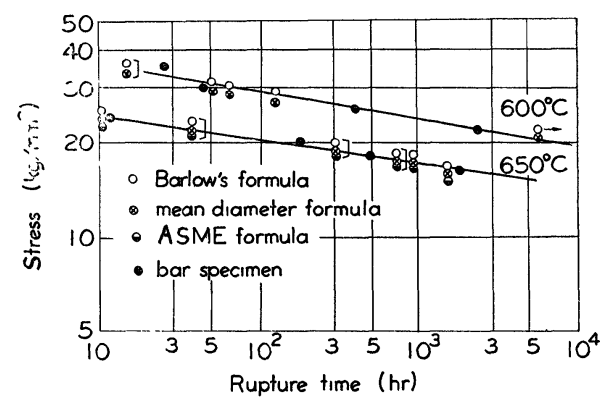

Fig. 2. Comparison of creep rupture data on thin-walled tubular and bar specimens of 18-8 Mo steel.

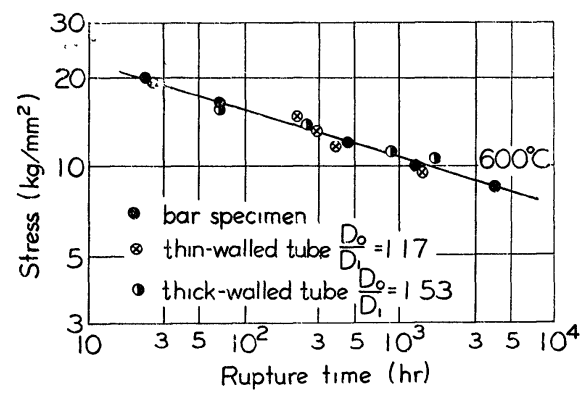

Fig.3. Comparison of creep rupture data on thickwalled and thin-walled tubular specimens of $21 / 4$ Gr-1 Mo steel. (Stress calculated by Mean diameter formula.) 
線図である，一軸クリープ破断の結果と比較してみる と大体平均径の式がよい一致を示している。

Fig. 3 は $600^{\circ} \mathrm{C}$ における $2 \frac{1}{4} \mathrm{Cr}-1 \mathrm{Mo}$ 鋼厚因鋼管の 内压クリープ破断試験の結果で，同一材による一軸ク リープ破断および薄肉鋼管の内圧クリープ破断の結果 も同時に示している. こてでは溥肉, 厚肉共に平均径 の式を用いて整理したものが比較的よく一軸の結果と 一致しているようである.今後オーステナイト系厚肉 鋼管についても笑験を予定しているが，乙れらは文献 によると $2 \frac{1}{4} \mathrm{Cr}-1 \mathrm{Mo}$ 鋼以上に平均径の式による 整理がよく合うようである。

Fig. 4 は低炭素鋼電縫鋼管の内王クリープ破断線図 である。この場合, 試験は $400^{\circ} \mathrm{C}, 450^{\circ} \mathrm{C}, 500^{\circ} \mathrm{C} の$ 各 温度で行ない，参考のため載せた継目無鋼管とは別々 の charge である. この結果をみると， $450^{\circ} \mathrm{C}$ 以下で は電縫鋼管のクリープ破断強度は継目無鋼管に充分匹 敵する。また破断位置も溶接部にかかわりなく，atrandom なところで起こっている。試験温度が $500{ }^{\circ} \mathrm{C}$ の場合には，（I）の絞り圧延のままのものは溶接部で 破断するものが增える傾向にあるが，（II）の絞り圧延 後焼準した材料は全部母材部で破断している.しかし， この温度で両者の間には強度的に全く差がない，この ような傾向は, 溶接法, 脱酸法等の改良により充分除 きうるものであるが，その原因となる因子については 現在倹討中である，いずれにしても，低炭素鋼ボイラ 管は $450^{\circ} \mathrm{C}$ 以下で用いられることから，充分垁用性が あると考えられる。

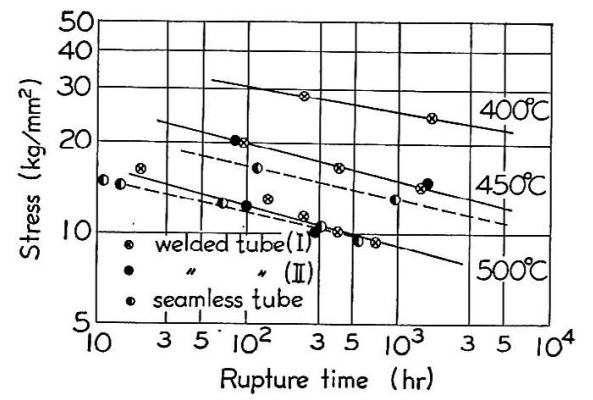

Fig.4. Stress rupture data on welded tubular specimens of low carbon steel. (Stress culculated by Mean diameter formulla).

鋼管の内圧クリープ破断試験の破断状沅の一例とし て Fig. 5 亿低若素鋼電縫鋼管の場合を示す. 比較的短 時間で破断したものが大きく口を開いている．との破 断部を桩大してみると短時間で破断したものと比較的 辰時閏で破断したものではその様子が相当異なってい る. Fig.6は 18-8 Mo 鋼の破断部である. 破断部で は内外面とも多数のクラックが発牛し，その一つから 破断が起こっている. Fig.7, Fig.8 は電縫鋼管の破断

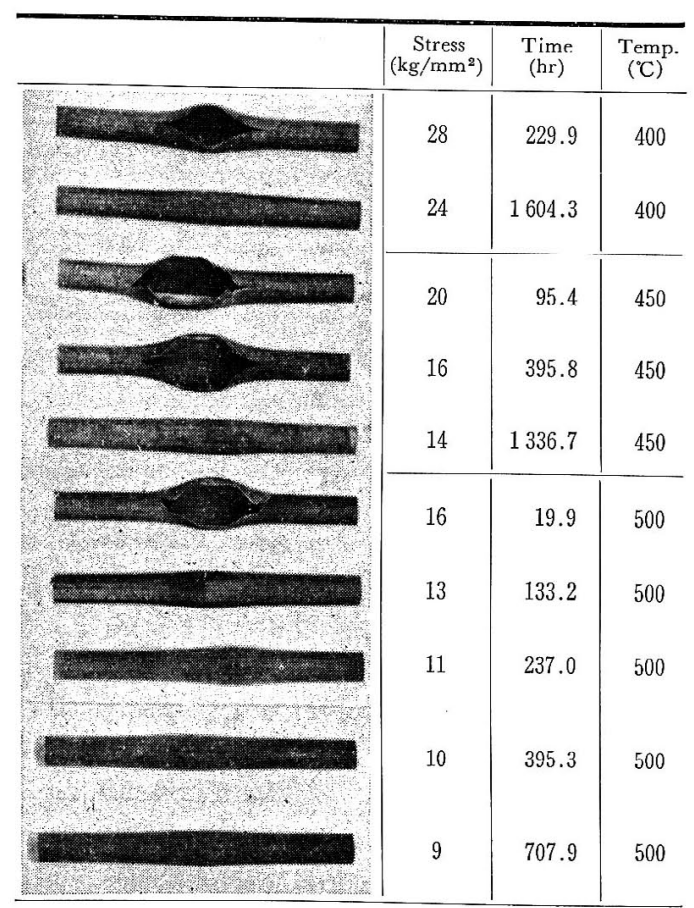

Fig.5. Rupture specimens of welded tube of a low carbon steel.

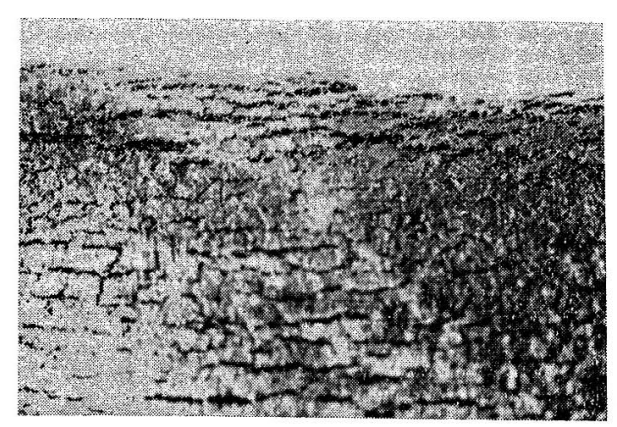

Outside appearance of rupture $\times 4$

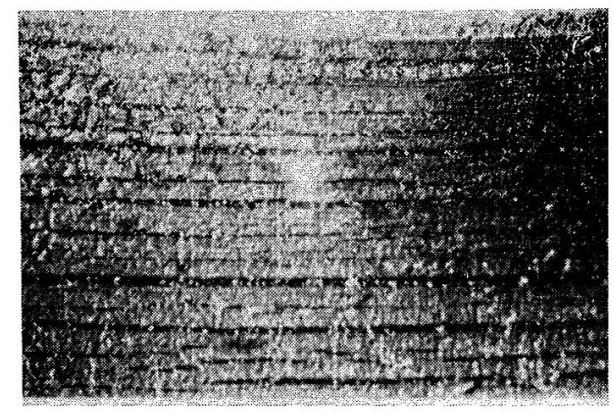

Inside appearance of rupture $\times 4$

Fig.6. Appearance of ruptured specimen of $18-8 \mathrm{Mo}$ steel. Temp. $650^{\circ} \mathrm{C}$, Stress $16.5 \mathrm{~kg} / \mathrm{mm}^{2}$, Time $873.2 \mathrm{hr}$. 


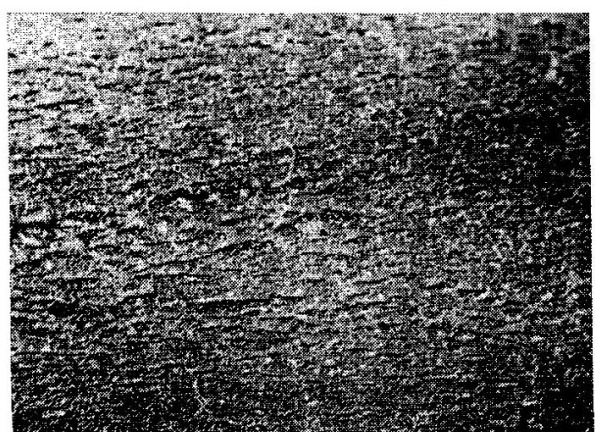

Outside appearance of rupture $\times 4$

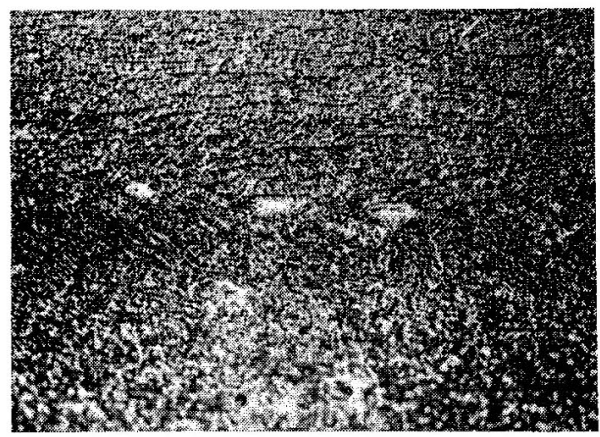

Inside appearance of rupture $\times 4$

Fig.7. Appearance of ruptured specimen of wclded tube I. Temp. $450^{\circ} \mathrm{C}$, Stress $14 \mathrm{~kg} / \mathrm{mm}^{2}$, Time 1336.7 hr., Rupture location (Base metal)

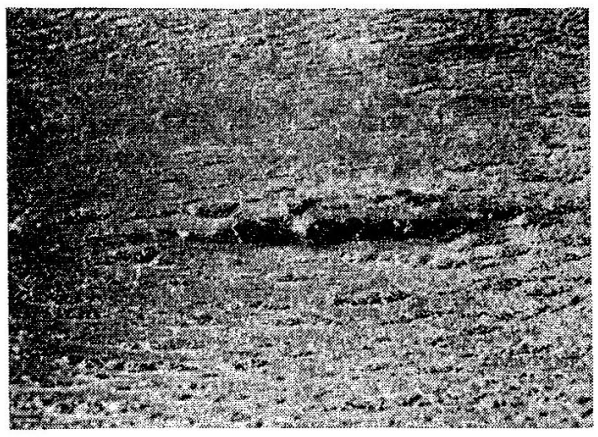

Outside appearance of rupture $\times 4$

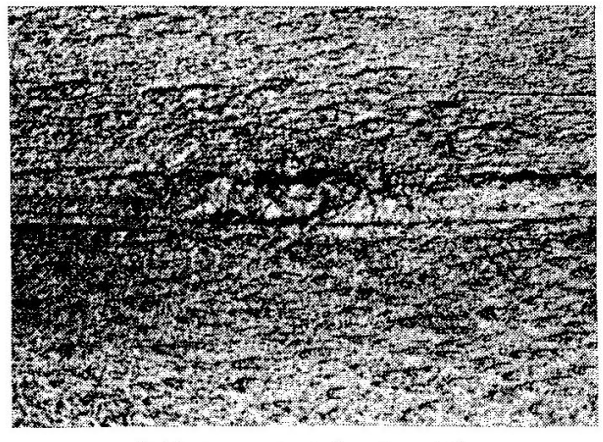

Inside appearance of rupture $\times 4$

Fig. 8. Appearance of ruptured specimen of welded tube I. Temp. $500^{\circ} \mathrm{C}$, Stress $11 \mathrm{~kg} / \mathrm{mm}^{2}$, Time 237.0hr., Rupture location (Weld part.)

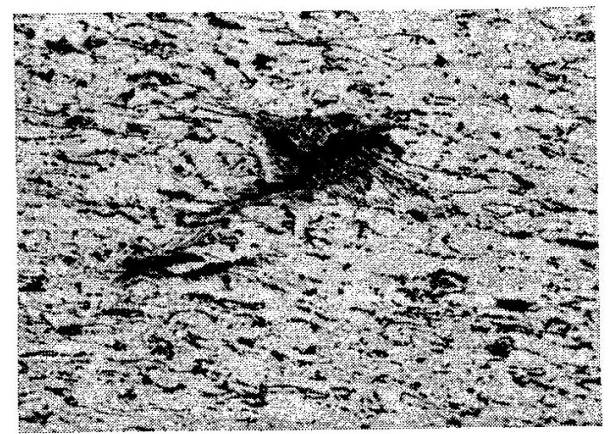

Temp. $400{ }^{\circ}$, Stress $24 \mathrm{~kg} / \mathrm{mm}^{2}$, Rupturc time $1604.3 \mathrm{hr}$., Rupture location (Base metal)

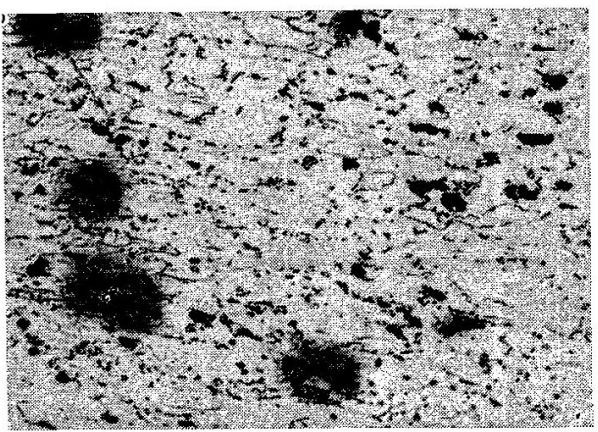

Temp. $450^{\circ} \mathrm{C}$, Strcss $11 \mathrm{~kg} / \mathrm{mm}$, Rupture time $1336.7 \mathrm{hr}$., Rupture location (Base metal)

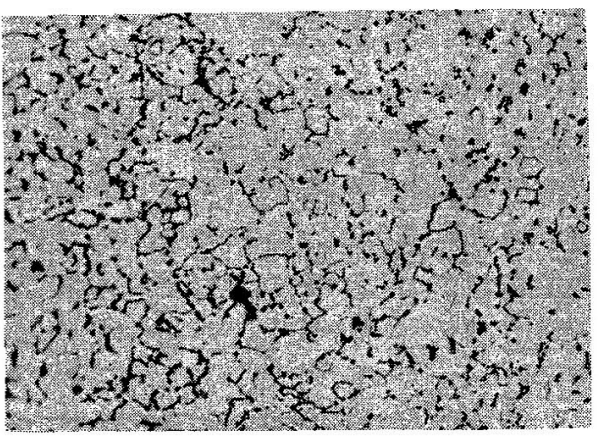

Temp. $500^{\circ} \mathrm{C}$, Stress $11 \mathrm{~kg} / \mathrm{mm}^{2}$, Rupture time $237.0 \mathrm{hr}$., Rupture location (Weld metal) $\times 500$

Fig. 9. Micro structure ruptured area of welded tube I.

部の拡大写真である. Fig.7 は母材部で破断したもの. Fig. 8 は溶接部で破断したものである.

破断部の顕微鏡組織は継目無鋼管については大体一 軸クリープ破断試験後のものと大差はないので，こて では電縫鋼管のクリープ破断後の組織をいくつか示す. Fig. 9 は $800^{\circ}$ 絞り圧延材の破断部の組織である。絞り の際の加熱により溶接部は焼きもどされ，母材部と溶 接部は光学顕微鏡では区別できない，組織は細かいフ ェライトとパーライトからなっており，破断部にはボ

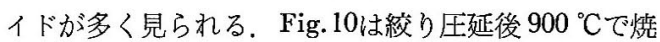
準した（II）の材料で母材部，溶接部とも典型的なフェ 


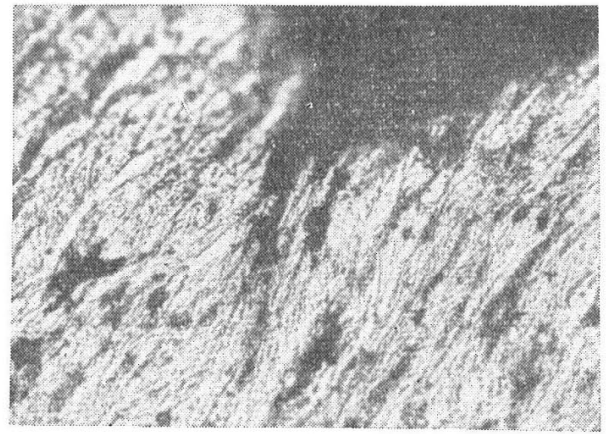

Ruptured area (Base metal)

Temp. 450 C, Stres3 $14.8 \mathrm{~kg} / \mathrm{mm}^{2}$, Rupture time $1348.3 \mathrm{hr}$.

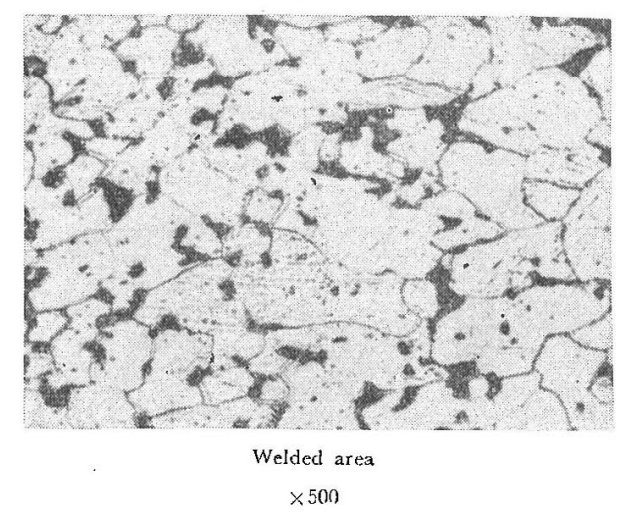

Fig. 10. Micro structure of welded tube II.

ライトとパーライト組織である。破断伸びについては 両者とも同じ程度である。

\section{5 考察}

今までいくつかの設計基準式を用いて鋼管の内圧ク リープ破断忍力と一軸引張応力状態におけるクリープ 破断応力とを比較した結果，平均径の式から計算した 破断応力によって整理すると, 薄肉, 厚肉によらず鋼 管の内圧りリープ破断応力は一軸わリープ破断応力と 比較的よく一致する。このような高温における鋼管の 内王クリープ破断は軸方向に割れ目が生じて破壊し， てれは内压によって発生する切線方向応力によるもの である. との切線方向応力について平，小寺沢，大谷 氏は厚肉鋼管の内圧クリープについての報告の中で， この応力が保荷直後の弾性的な応少分布から比較的短 時間の間に管壁にわたって平均化され，この状態はわ ずかの変化をもって10万時間以上持続するとと，そし て管壁にわたって平均化された切線応力の下でクリー プが進行すると発表されている．Fig.11はての報告の 中の応力分布の変化についての図を転載したものであ る.したがって，内非クリープ破断についても同様の 経過でクリープ過程中に管壁にわたって切線方向応力 が可均化されて，ての状熊で長時間にわたってクリー プが進行し，遂には破断に至たるものであろう。この ような垺密なクリープ理論によって求められた切線方

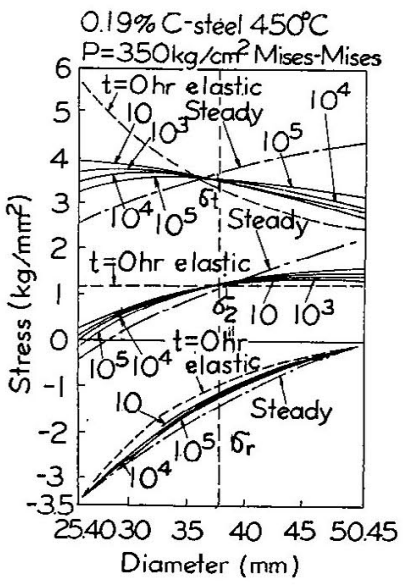

Fig.11. Stress distribution in thick-walled tubes under elastic and creep condition. (by S. Taira. ${ }^{5}$ )

向応力あるいは相当応力と平均径の式による応力との 関係等については現在愉討中であり次の機会に讓る。

てのような鋼管の内压クリープ破断応力を一軸クリ 一プ破断応才と一致させるような設計式を求める弪み は，最近英国において10000時閔以上にわたる大規模 な実験が行なわ能，その中間報告がなされている。そ の結果によると，温度，応力，鋼種，管の方法等によ らず平均径の式が最も適合性があると結論ずけられ， 高温内圧円筒の設計基準（BS）の改訂の基礎となって いる.

\section{6 結 ひ}

（1）平均往の式によって求めた鋼管の内压クリープ 破断応力は薄图，厚肉にかかわらず一軸引張クリープ 破断応力と良据な一致を示す.

(2) 一朝クリープ破断試験によっては求められない 不均質部が存在する鋼管たとえば電縫鋼管や鋼管の溶 接継手等のクリープ破断強度が内归クリープ試験によ り容易に求められる。

（3）この試験に用いた電縫銅管は初期の試作品であ るので製鎆法，溶接法等ボイラ用として必ずしも最良 のものとは考えられないが，継目無鎆管に比べてあま り遜色のないろりープ破断強度を示した．したがって， 霞縫鋼管はボイラ用として充分実用に供し得るものと 思われる。

(昭和39年 9 月 8 日 第 7 回高温強度シンポジウムにて講演)

\section{参考 文 献}

1）管田 瞕, 會貫好雄, 玉田 公, 材料, 13, 157 (1964),

2) Garlson, W.B., and D. Duval, Rept. Birt. Elec. and Aplied Ind.Reseach Assoc., J T182 p.1 (1962).

3) Ghitty, A., and D. Duval, Proc. Joint Int. Conf. on Creep, p. 4-1 (1963) New York.

4) 将 修二, 小寺沢良一, 大谷隆一，材料， 13，163 (1964).

5) 西 修二, 第 9 回「村料の強度と虔学シンポジウ」 予稿, p.1 (1964). 